\title{
Factors affecting the burden on caregivers of stroke survivors in Turkey
}

\author{
Umit Gorgulu ${ }^{1 *}$, Ulku Polat ${ }^{2}$, Burcu Bayrak Kahraman ${ }^{2}$, Sukru Ozen $^{2}$, Ersin Arslan ${ }^{3}$
}

\begin{abstract}
Objective: Caring for stroke patients leads to caregiver strain. Caregiver burden following stroke is increasingly recognised as a significant health care concern. This study was conducted to determine factors affecting the burden on caregivers of stroke survivors.
\end{abstract}

Material and Method: This was a descriptive study. Eighty caregivers of stroke patients hospitalized in the intensive and intermediate intensive care clinics of the Neurology Department of the Gazi University Health Research and Application Centre were included in the study. The caregiver introductory form, Barthel index (BI), National Institutes of Health Stroke Scale, Pittsburgh sleep quality index (PSQI) and caregiver burden scale (CBS) were used to collect the data.

Results: In our study, a significant negative relationship $(\mathrm{r}=-0.854, \mathrm{p}=0.000)$ was determined between the mean $\mathrm{BI}$ scores (24.55 \pm 7.69$)$ and the mean CBS scores (57.52 \pm 14.35$)$ and a significant positive relationship was determined between the mean CBS and the mean PSQI daytime dysfunction sub-component scores $(1.30 \pm 1.42 ; \mathrm{r}=0.223 ; \mathrm{p}=0.046)$.

Conclusion: The burden of care could become so excessive as to negatively impact the caregivers' sleep quality. Our study has demonstrated that caregiver burden increased as the level of independence of stroke patients decreased and daytime dysfunction sleep disorder became more prevalent as the caregivers' burden increased. To reduce the negative impact of burden of care, influencing factors should be determined.

Keywords: Caregivers, sleep, stroke, survivors

\section{Introduction}

Stroke is defined as an acute neurological disorder that develops after the decrease of cerebral blood flow in a certain part of the brain caused by vascular damage (1). Causing mortality and morbidity, stroke is an important disease and is the second leading cause of death in the world and in our country, Turkey $(2,3)$. Complete recovery is not possible for many stroke survivors and these patients have to suffer permanent cognitive and functional sequelae for the rest of their lives. In this period, patients and their caregivers try to cope with many problems such as regression in musculoskeletal system functions, nutritional changes, elimination and loss of senses, and they try to adjust to changes in their daily lives (4). The care of stroke patients is usually undertaken by family members. McCullagh et al. (5) reported that it is identified that $70 \%$ of caregivers are the patient's spouse and $22.8 \%$ are the patient's child.
In our country, generally caregivers are the family members of the patient and caregiving is perceived to be an interfamilial responsibility (6). In our country, in a similar study conducted by Asiret and Kapucu (7), it is indicated that $42.9 \%$ of caregivers are the patient's spouse and $50 \%$ are the patient's child. Caregiving, defined as the process of undertaking caregiving activities and responsibilities, does not merely consist of meeting the physical needs of patients, it also requires the caregiver to provide the patient with emotional, social, and financial support (6,7). From this point of view, the multi-dimensional functional disorder of the patient entails extensive and long-term care and affects not only the patient but also the patient's relative who undertakes the caregiving responsibility $(8,9)$. Being a difficult process, poststroke caregiving may affect the caregiver in certain respects such as her/his physical and emotional health, work life, and social relations (8). As caregiving responsibilities increase, the relationship between the caregiver and care receiver may turn

\footnotetext{
Received: 22-12-2015, Accepted: 07-01-2016

${ }^{1}$ Nizip State Hospital, Clinic of Neurology, Gaziantep-Turkey

${ }^{2}$ Gazi University Faculty of Medicine, Department of Nursing, Ankara-Turkey

${ }^{3}$ Dr. Ersin Aslan State Hospital, Clinic of Thoracic Surgery, Gaziantep-Turkey

*Corresponding Author: Umit Gorgulu E-mail: drumitgorgulu@hotmail.com
} 
into a one-sided, dependent, and lasting obligation that causes discomfort in the caregiver's life. This situation is known as 'caregiver burden'. Caregiver burden is defined as the physical, psychological, and financial responses that may be observed during the caregiving process and occurs when the caregiver suffers from difficulties, experiences high levels of strain, feels pressure, and undertakes the caregiving burden $(9,10,11)$. After a while, various problems emerge that influence the health condition of the caregiver. Not allocating enough time for his/ her self-care, chronic fatigue, changes in body weight, sleep disorder, muscle pain (myalgia), and concentration impairment are common problems. Doubtless, the caregiving burden of the caregivers of stroke patients is affected by and differentiated according to the level of dependence, personal characteristics, and the duration of the caregiving process. Likewise, in a study conducted by Mollaoglu et al. (6) a significant positive relationship was found between the level of dependence of patients and the caregiving burden of their caregivers. When the related literature on strokes is examined, although the poststroke caregiving burden and the affecting factors are frequently addressed, it is observed that the problems encountered by caregivers are mentioned less and their sleep quality is not evaluated at all $(6,7,9,12-14)$. In our study, we aimed to compare the level of functional independence of stroke patients and the burden of care and sleep quality of caregivers.

\section{Material and Methods}

The caregivers of stroke patients hospitalized in intensive and intermediate intensive care clinics of the Neurology Department of the Gazi University Health Research and Application Centre were included in the population of the cross-sectional study. The study included caregivers of 80 patients, who were literate, did not have communication difficulties, and who participated voluntarily. Data collection instruments used in the study were the caregiver introductory form, Barthel index (BI) and National Institute of Health Stroke Scale (NIHSS) for the identification of the independence levels of the patients, Pittsburgh sleep quality index (PSQI) to identify the quality of sleep of caregivers, and the caregiver burden scale (CBS) to define the burden of caregivers.

\section{Instruments}

\section{Barthel index}

The BI, is frequently used for the evaluation of daily functions, and was developed by Mahoney and Barthel in 1965 (15). This index measures the independence of a person in activities of daily living without help; such as feeding, toileting, bathing, and movement inside and outside a building. Its validity and reliability studies were conducted by Kucukdeveci et al. (16) with neurology patients. The total score of the index is 100 ; scores of 0-20 mean a person is fully dependent, 21-61 severely dependent, 62-90 moderately dependent, 91-99 slightly dependent, and 100 fully independent (16).

\section{Caregiver burden scale}

The CBS was developed by Zarit et al. (17) in 1980 in order to measure the stress of caregivers providing assistance to a person or elderly people needing care. The validity and reliability studies of the scale in Turkish were conducted by Inci and Erdem (18) in 2006. The scale, which can be filled in by either the caregiver himself or through questions by a researcher, is comprised of a series of 22 questions that determine the effects of caregiving on the life of caregivers. The tool has a five-point Likert-type assessment scale that ranges from ' $0=$ never' to ' $4=$ almost every time'. The minimum possible score is 0 and the maximum score is 88 . The sections on the scale are generally related to social and emotional dimensions and high scores on the scale indicate high levels of discomfort (18).

\section{Pittsburgh sleep quality index}

This index was developed by Buysse et al. (19) in 1989 and provides detailed data on the type and severity of sleep quality and sleep disorder during the previous month. Its validity and reliability studies in Turkey were conducted by Agargun et al. (20) in 1996. The scale includes 24 questions and is comprised of seven components. These are: Self-rated sleep quality, sleep latency, sleep duration, habitual sleeping activity, sleep disorder, use of sleeping pills, and daytime dysfunction. The total points received in these seven components give the total scale score, which is between 0-21. A high total score indicates low quality of sleep (20).

\section{National Institute of Health Stroke Scale}

This scale, which is used in the observation of stroke patients to determine the severity of stroke, was designed by the US National Institute of Health (21). The scale measures level of consciousness, conscious responses to questions, response to commands, extra-ocular muscle movements, visual fields, facial palsy, motor strength of lower and upper extremities, limb ataxia, sensory loss, aphasia, dysarthria, and neurological neglect. It grades the existing problems on a two- to three-point scale ( $0-3$ points, according to the question) and is comprised of a total of 11 components, one of which has three subcomponents. In total 36 points can be scored on the scale and lower scores indicate better post-stroke clinical condition (21).

\section{Statistical analysis}

The Statistical Package for Social Sciences version 16.0 program was used in the evaluation of the data in our study. Percentage, average, Student's t-test (for independent samples), Mann-Whitney U test, Kruskal-Wallis test, one-way analysis of 
variance (ANOVA), and Pearson correlation analysis were used in the statistical analysis.

\section{Ethical considerations}

In order to conduct the study, written permission was received from the Gazi University Social Studies Ethics Committee (January 25， 2013/No: 66868116-604.01.02-15-1934). Directorate, the institution where the study was conducted, and also from the volunteers who took part in the study.

\section{Results}

The average age of participants in the study was $\bar{X}=46.10 \pm 16.21$; $76.3 \%$ of the participants were female, $76.3 \%$ married, $80 \%$ had children, and $32.5 \%$ were primary school graduates. Half of the caregivers $(50 \%)$ stated that they lived with the patient, $82.5 \%$ gave one to six months of care and nearly half (48.8\%) stated that they provided care without any help from others. Fifty-five percent of stroke patients were cared for by their children and $21.3 \%$ by their spouse. Regarding caregiving, it was indicated that $36.3 \%$ neglected their self-care, $32.5 \%$ had problems in interpersonal relations, and $26.2 \%$ had economic problems. Additionally, it was identified that the majority of caregivers (73.8\%) did not have prior caregiving experience and the great majority of them $(86.2 \%)$ had poor health. According to the BI score, in terms of the levels of dependence of the patients, $41.3 \%$ of the patients were fully dependent and $23.8 \%$ of them were severely dependent (Table 1).

When the average scores of the CBS are examined according to the demographic characteristics of caregivers, a statistically significant relationship was not observed between the scores in the CBS and the age, gender, educational status, economic status, or parental status of caregivers, as well as the duration of caregiving. However, a statistically significant relationship was determined between their marital status, their prior caregiving experience, poor health, and their scores on the CBS. In our study it was identified that the CBS score of single caregivers who had prior caregiving experience and poor health was higher than those of caregivers who were married, had no prior caregiving experience, and poor health (Table 1). There was a statistically significant relationship between the levels of dependency of the patients and their average score on the CBS.

In our study, it was determined that the average NIHSS score of stroke patients is $7.86 \pm 7.99$, average BI scores are 24.55 \pm 7.69 , average CBS score is $57.52 \pm 14.35$ and PSQI score is 7.40 \pm 3.18 . When the NIHSS and BI scores of stroke patients are compared with their total scores on the CBS and PSQI, a significant positive relationship was found $(\mathrm{r}=0.854, \mathrm{p}=0.000$; $\mathrm{r}=0.223, \mathrm{p}=0.046)$ between average BI scores $(\overline{\mathrm{X}}=24.55 \pm 7.69)$ and CBS scores $(\bar{X}=57.52 \pm 14.35)$, but a significant relationship was not found $(\mathrm{r}=0.080, \mathrm{p}=0.482)$ between average $\mathrm{BI}$ scores $(\overline{\mathrm{X}}=24.55 \pm 7.69)$ and PSQI scores $(\overline{\mathrm{X}}=7.40 \pm 3.18)$. When the relationship between the sub-components of the BI and PSQI are examined, a significant positive relationship was observed $(r=0,854, p=0.000 ; r=0.223, p=0.046)$ between the sub-component of CBS (57.52 \pm 14.35$)$ and sub-component of daytime dysfunction $(\bar{X}=1.30 \pm 1.42)$. However, a significant relationship was not found ( $\mathrm{p}>0.05)$ between the NIHSS scores $(\overline{\mathrm{X}}=7.86 \pm 7.99)$ and the average score of PSQI scores $(\overline{\mathrm{X}}=7.40 \pm 3.18)$ and the CBS scores $(\overline{\mathrm{X}}=57.52 \pm 14.35)$ (Table 2).

\section{Discussion}

Post-stroke care of patients is provided primarily by family members. Also it was determined in our study that stroke patients are provided care firstly by their children and spouses. In a study conducted by Hung et al. (22) on caregivers of stroke patients, it was indicated that the majority of caregivers are the spouse (44\%) and children (33\%) of the stroke patient. In another study by Akosile et al. (23), it was found that $55.2 \%$ of stroke patients are provided care by their children. In another study conducted in our country, it was found that half of stroke patients are cared for by their children (7). This situation might be their voluntary decision; it may also turn out to be an absolute necessity due to the insufficient number of places in institutions providing care for stroke patients. For our country, providing care to stroke patients within the family is a reflection of our cultural structure.

Stroke caregivers may encounter many emotional, cognitive, economic, and social problems (6). Indeed, the participant caregivers in our study often expressed that they neglected their self-care, their interpersonal relations had deteriorated, and they had economic problems. In addition, it was determined in our study that caregivers with poor health had greater caregiver burden. It is thought that these results are associated with the perceived stress and caregiving burden of the caregivers. In certain studies it was indicated that, associated with caregiver burden and stress, caregivers experienced psychosocial difficulties and their physical and mental health and self-care behaviour was affected $(24,25)$. In another study conducted by Tuna and Olgun (9), more than half of the caregivers stated that their health was adversely affected due to the caregiving process and that they experienced physical and psychological problems. It is thought that these problems have a negative effect on caregivers' quality of life. In studies conducted with the aim of determining the caregiving burden and quality of life of post-stroke caregivers, it was indicated that an increase in care burden decreased quality of life $(5,14,22)$.

It was indicated in the related literature that the increase in the burden of caregivers was caused by the intense stress they 
Table 1: Average caregiver burden scores according to introductory characteristics of caregivers

Characteristics

Age (years)

20-34

$35-49$

50-64

65 and above

Gender

Male

Female

Marital status

Married

Single

Parental status

Have children

Do NOT have children

Educational status

Literate

Primary school

Secondary school

High school

University

Economic status

Good

Fair

Degree of caregiver relationship closeness

Spouse

Child

Attendant

Mother

Other

Living together with the patient

Living

NOT living

Duration of caregiving

1-6 months

7 months and longer

Manner of caregiving

Without help

With help

Prior caregiving experience

Have

Have NOT

Health problem

Have

Have NOT

Level of dependence according to Barthel index score $* * *$

$0-20$ points

21-60 points

$61-90$ points

91-100 points

a: Kruskal-Wallis test for, $\mathrm{b}$ : Mann-Whitney $U$ Test was used for, $\mathrm{c}$ : Student's $\mathrm{t}$ test for, SD: Standard deviation, *Man ${ }^{*}$ Marson correlation between the average scores of Caregiver Burden scale and Barthel index: $\mathrm{R}=-0.232, \mathrm{p}=0.039$ \begin{tabular}{|l|l|}
\hline$\overline{\mathrm{X}} \pm$ SD & $\mathbf{p}$ \\
\hline
\end{tabular}

\begin{tabular}{|l|l|}
\hline 20 & 25. \\
\hline 26 & 32.5 \\
\hline 25 & 31.2 \\
\hline 9 & 11.3 \\
\hline
\end{tabular}

\begin{tabular}{|l|l|}
\hline 25.0 \\
\hline 32.5 \\
\hline 31.3 \\
\hline 11.3 \\
\hline
\end{tabular}

$55.65 \pm 12.11$

$61.00 \pm 14.49$

$53.52 \pm 16.06$

$62.77 \pm 11.16$

61

\begin{tabular}{l|l|l|l}
\hline 19 & 23.8 & $56.73 \pm 12.69$
\end{tabular}

\begin{tabular}{|l|l}
61 & 76.2 \\
\hline 19 & 23.8 \\
\hline
\end{tabular}

$55.54 \pm 14.94$

$63.89 \pm 10.14$

\begin{tabular}{l|l|l|l}
64 & 80.0 & $57.01 \pm 14.56$ \\
\hline
\end{tabular}

\begin{tabular}{l|l|l|l}
\hline 16 & 20.0 & $59.56 \pm 13.70$
\end{tabular}

\begin{tabular}{|l|l|l|}
5 & 6.3 & $67.40 \pm 14.44$ \\
\hline
\end{tabular}

\begin{tabular}{l|l}
26 & 32.5 \\
\hline & 12.5
\end{tabular}

\begin{tabular}{l|l|l|}
\hline 10 & 12.5 \\
\hline
\end{tabular}

\begin{tabular}{l|l|l}
\hline 21 & 26.3 \\
\hline
\end{tabular}

$51.80 \pm 13.37$

$58.90 \pm 11.76$

$60.57 \pm 16.02$

\begin{tabular}{l|l|l}
18 & 22.5 & $58.72 \pm 13.29$
\end{tabular}

\begin{tabular}{|l|l|l}
\hline 16 & 20.0 & $56.56 \pm 13.02$ \\
\hline 64 & 80.0 & $57.76 \pm 14.74$ \\
\hline
\end{tabular}

\begin{tabular}{l|l|l|l}
\hline 64 & 80.0 & $57.76 \pm 14.74$
\end{tabular}

$p=0.527 b$

\begin{tabular}{|c|c|c|c|}
\hline 17 & 21.3 & $55.47 \pm 17.75$ & \multirow[t]{5}{*}{$* * p=0.005 a$} \\
\hline 44 & 55.0 & $62.40 \pm 12.52$ & \\
\hline 4 & 5.0 & $46.00 \pm 12.46$ & \\
\hline 5 & 6.3 & $46.00 \pm 6.20$ & \\
\hline 10 & 12.5 & $49.90 \pm 10.31$ & \\
\hline
\end{tabular}

\begin{tabular}{|l|l|l|l}
\hline 40 & 50.0 & $58.80 \pm 16.48$ & $\mathrm{p}=0.430^{\mathrm{c}}$ \\
\hline 40 & 50.0 & $56.25 \pm 11.92$ &
\end{tabular}

\begin{tabular}{|l|l|l|l}
\hline 66 & 82.5 & $56.72 \pm 14.23$ & $\mathrm{p}=0.209 \mathrm{~b}$ \\
\hline 14 & 17.5 & $61.28 \pm 14.83$ &
\end{tabular}

39

\begin{tabular}{|l|l}
39 \\
41
\end{tabular}

\begin{tabular}{|l|l|}
39 & 48.8 \\
\hline 41 & 51.3 \\
\hline
\end{tabular}

\section{8}

51.3

$57.23 \pm 14.76$

$57.80 \pm 14.12$

\begin{tabular}{|l|l|}
\hline 21 & 26.3 \\
\hline 59 & 73. \\
\hline & \\
\hline 69 & 86.3 \\
\hline 11 & 13.8 \\
\hline
\end{tabular}

$52.09 \pm 13.89$

$59.45 \pm 14.12$

$59.18 \pm 13.75$

$47.09 \pm 14.20$

$p=0.859 c$

\begin{tabular}{|l|l|l|l|}
\hline 33 & 41.3 & $59.45 \pm 13.70$ & $* * \mathrm{p}=0.037$ \\
19 & 23.8 & $59.21 \pm 12.83$ & \\
18 & 22.5 & $59.00 \pm 15.13$ & \\
10 & 12.5 & $45.30 \pm 13.67$ & \\
\cline { 1 - 2 } & &
\end{tabular}

15.30 13.67 
experienced, adversely affecting their physical and emotional health, working and social life, and economic status. In addition, it was also stated that the caregiver experienced difficulties especially regarding his/her mental health and social life and that there was a significant positive relationship between caregiver burden and health-related quality of life $(8,26,27)$. In a study conducted by van den Heuvel et al. (13) to determine the burnout risk factor of caregivers, it was indicated that younger caregivers with poor physical health had higher risk factors for burnout. Rombough et al. (28) indicated a significant positive relationship between the health problems of caregivers and caregiver burdens. Mollaoglu et al. (6) observed that caregivers with health problems had higher scores of caregiver burden.

It is known that caregiver burden is affected by many factors regarding the caregiver and their patient (11). These factors are the caregiver's age, gender, marital status, degree of caregiver's relationship closeness, educational status, economic conditions, and the patient's cognitive and functional inadequacies, presence of caregiving assistance, and the personal characteristics of the patients $(7,11,29)$. In our study, it is indicated that the caregiving burden of single caregivers is greater than those of married ones. A similar result was obtained in a study conducted by Zaybak et al. (30) for the identification of caregiving burden of caregivers of bedridden patients, where it was observed that caregiver burden was greater for single caregivers. The reason for this is that single caregivers receive less support from other people in caregiving activities and that their coping abilities are insufficient. It was also established in our study that caregivers who do not have prior caregiving experience have a greater burden. This is supported by results of other studies $(11,31)$.

In addition to this, a significant negative relationship has been found between the levels of dependence of stroke patients and the CBS score. It was established in some studies that as the level of dependence increases, daily life activities of the patient deteriorate and in further stages there occurs a significant increase in caregiver burden (32-36). Similarly, in a study conducted by Mollaoglu et al. (6) significantly high scale scores were observed on the part of caregivers whose patients are dependent according to the BI and who meet all patients' needs. Parallel to the results of our study, Carod-Artal et al. (37) indicated a negative relationship between the functional status of stroke patient caregivers and caregiver burden.

In our study, a significant positive relationship was found between caregiver burden and daytime dysfunction among the sub-components of the PSQI. Sleep disorder is mentioned in the literature among the most important problems that caregivers suffer $(7,35,38,39)$. Asiret and Kapucu (7) indicated that relatives of patients encounter psycho-social problems, fatigue, and sleeplessness. In a study conducted with caregivers of patients with congestive heart failure, it was indicated that $90 \%$ of caregivers suffered from sleep disorders (39).

In a study conducted by Creese et al. (38) with Alzheimer patients, it was indicated that $63 \%$ of caregivers had sleep problems. Das et al. (40) determined in their study that caregivers of stroke patients have physical, mental, and economic stress, anxiety and depression (76\%), and sleep disorders (43\%) associated with increasing burden $(70 \%)$. The results from these studies show that it is important to know and reveal factors affecting the burden on caregivers of stroke survivors in order to improve the quality of life of patients and their caregivers.

\section{Conclusions}

Individuals who care for stroke patients have difficulty in many areas, and this increases the burden of their care. As a result of our study, it is determined that caregivers suffer health problems associated with their caregiving burden and as the functional

Table 2: Comparison of National Institute of Health Stroke Scale, Barthel index, sleep quality, and caregiver burden scale scores of stroke patients

\begin{tabular}{|l|l|}
\hline Scales & Average scores \\
\hline National Institute of Health Stroke Scale & $7.86 \pm 0.99$ \\
\hline Pittsburgh sleep quality index* & $7.40 \pm 3.18$ \\
\hline Self-rated sleep quality & $1.16 \pm 0.64$ \\
\hline Sleep latency & $2.68 \pm 1.53$ \\
\hline Sleep duration & $0.81 \pm 0.87$ \\
\hline Habitual sleeping activity & $0.08 \pm 0.39$ \\
\hline Sleep disorder & $1.72 \pm 0.67$ \\
\hline Use of sleeping pills & $0.10 \pm 0.37$ \\
\hline Daytime dysfunction & $1.30 \pm 1.42$ \\
\hline Caregiver burden scale* & $57.52 \pm 14.35$ \\
\hline
\end{tabular}

*The Pearson correlation between average scores of caregiver burden scale and daytime dysfunction is $0.223, \mathrm{p}=0.046<0.05$ 
levels of dependence of patients decline, their caregiving burden increases. In addition, it was observed that daytime dysfunction is more prevalent among sleep disorders associated with the increase of caregiving burden. This descriptive analysis demonstrates the important relationship between level of functional independence of patients, caregiver burden and sleep quality, and can lead to interventions to diagnose and treat sleep disorders and develop strategies to improve the quality of life of caregivers.

In light of these results, it is recommended that care providers' burdens should decrease with cooperation of the family members and should provide all necessary support and assistance, and should direct them to the support groups. In addition, it is advised that the burden of caregivers of stroke patients and the factors affecting it, should be defined and health professionals should include caregivers in the care plan while examining patients because caregivers may experience negative health effects.

\section{References}

1. Ulusoy EK, Albayrak T, Kasım İ, Yön Mİ. İntravenous thrombolitic treatment in acute ischemic stroke: The awareness patient selection and transfer. Turk J Med Sci. 2012;6:28-32.

2. Gaziano TA. Cardiovascular disease in the developing world and its cost-effective management. Circulation. 2005;112:3547-3553.

3. World Health Organisation (WHO). Chronic diseases and health promotion. STEP wise approach to stroke surveillance. http:// www. who.int/chp/ steps/stroke/en/ (Accessed 01.09.14).

4. Bilgili N, Gözüm S. İnmeli hastaların evde bakımı: Bakım verenler için rehber. Dokuz Eylül Üniversitesi Hemșirelik Yüksekokulu Elektronik Dergisi. 2014;7:128-150.

5. McCullagh E, Brigstocke G, Donaldson N, Kalra L. Determinants of caregiving burden and quality of life in caregivers of stroke patients. Stroke. 2005;36:2181-2186.

6. Mollaoğlu M, Tuncay FÖ, Fertelli TK. İnmeli hasta bakım vericilerinde bakım yükü ve etkileyen faktörler. Dokuz Eylül Üniversitesi Hemşirelik Yüksekokulu Elektronik Dergisi. 2011;4:125-130.

7. Aşiret GD, Kapucu S. İnmeli hastalara bakım veren hasta yakınlarının bakım yükü. Hemşirelikte Araştırma Geliştirme Dergisi. 2012;14:7380.

8. Opara JA, Jaracz K. Quality of life of post-stroke patients and their caregivers. J Med Life. 2010;3:216-220.

9. Tuna M, Olgun N. İnmeli hastalara bakım veren hasta yakınlarında görülen tükenmişlik durumunda algılanan sosyal desteğin rolü. Hacettepe Üniversitesi Sağlık Bilimleri Fakültesi Hemşirelik Dergisi. 2010;17:41-52.
10. Kasuya RT, Polgar-Bailey P, Takeuchi R. Caregiver burden and burnout: A guide for primary care physicians. Postgrad Med. 2000;108:119-123.

11. Atagün Mİ, Balaban ÖD, Atagün Z, Elagöz M, Özpolat AY. Kronik hastalıklarda bakım veren yükü. Psikiyatride Güncel Yaklaşımlar. 2011;3:513-525

12. Chow SK, Wong FK, Poon CY. Coping and caring: support for family caregivers of stroke survivors. J Clin Nurs. 2007;16:133-143.

13. van den Heuvel ET, de Witte LP, Schure LM, Sanderman R, Meyboomde Jong B. Risk factors for burn-out in caregivers of stroke patients, and possibilities for intervention. Clin rehabil. 2001;15:669-677.

14. Morimoto T, Schreiner AS, Asano H. Caregiver burden and healthrelated quality of life among Japanese stroke caregivers. Age Ageing. 2003;32:218-223.

15. Mahoney FI, Barthel DW. Functional evaluation: The Barthel Index. Md State Med J. 1965;14:61-65.

16. Küçükdeveci AA, Yavuzer G, Tennant A, Süldür N, Sonel B, Arasil T Adaptation of the modified Barthel Index for use in physical medicine and rehabilitation in Turkey. Scand J Rehabil Med. 2000;32:87-92.

17. Zarit SH, Reever KE, Bach-Peterson J. Relatives of the impaired elderly: Correlates of feelings of burden. Gerontologist. 1980;20:649655 .

18. İnci $F H$, Erdem M. Bakım verme yükü ölçeğinin Türkçe'ye uyarlanması, geçerlilik ve güvenilirliği. Atatürk Üniversitesi Hemşirelik Yüksekokulu Dergisi. 2008;11:85-94.

19. Buysse DJ, Reynolds CF, Monk TH, Berman SR, Kupfer DJ. The pittsburgh Sleep Quality Index: A new instrument for psychiatric practice and research. Psychiatry Res. 1989;28:193-213.

20. Ağargün MY, Kara H, Anlar O. Pittsburgh uyku kalitesi indeksinin geçerliği ve güvenirliği. Türk Psikiyatri Dergisi. 1996;7:107-115.

21. Brott T, Adams HP Jr, Olinger CP, Marler JR, Barsan WG, Biller J, et al. Measurements of acute cerebral infarction: A clinical examination scale. Stroke. 1989;20:864-870.

22. Hung JW, Huang YC, Chen JH, Liao LN, Lin CJ, Chuo CY, et al Factors associated with strain in informal caregivers of stroke patients. Chang Gung Med J. 2012;35:392-401.

23. Akosile CO, Okoye EC, Adegoke BOA, Mbada CE, Maruf FA, Okeke IA. Burden, health and quality of life of Nigerian stroke caregivers Health Care Current Rewievs. 2013;1:1-5.

24. Lu YF, Wykle M. Relationships between caregiver stress and self-care behaviors in response to symptoms. Clin Nurs Res. 2007;16:29-43.

25. Merluzzi TV, Philip EJ, Vachon DO, Heitzmann CA. Assessment of self-efficacy for caregiving: The critical role of self-care in caregiver stress and burden. Palliat Support Care. 2011;9:15-24. 
26. Ilse IB, Feys H, de Wit L, Putman K, de Weerdt W. Stroke caregivers' strain: Prevalence and determinants in the first six months after stroke. Disabil Rehabil. 2008;30:523-530.

27. Saban KL, Sherwood PR, DeVon HA, Hynes DM. Measures of psychological stress and physical health in family caregivers of stroke survivors: A literature review. J Neurosci Nurs. 2010;42:128-138.

28. Rombough RE, Howse EL, Bartfay WJ. Caregiver strain and caregiver of primary caregivers of stroke survivers with and without aphasia. Rehabil Nurs. 2006;31:199-209.

29. Lai DWL. Effect of financial costs on caregiving burden of family caregivers of older adults. SAGE Open. 2012;2:1-14.

30. Zaybak A, Güneş ÜY, İsmailoğlu EG, Ülker E. Yatağa bağımlı hastalara bakım veren bireylerin bakım yüklerinin belirlenmesi. Anadolu Hemşirelik ve Sağlık Bilimleri Dergisi. 2012;15:48-54.

31. Malak AT, Dicle A. Beyin tümörlü hastalarda bakım verenlerin yükü ve etkileyen faktörler. Türk Nöroșirürji Dergisi. 2008;18:118-121.

32. Gayomali C, Sutherland S, Finkelstein FO. The challenge for the caregiver of the patient with chronic kidney disease. Nephrology Dialysis Transplant. 2008;23:3749-3751.

33. Greenwood N, Mackenzie A, Cloud GC, Wilson, N. Informal carers of stroke survivors-factors influencing carers: A systematic review of quantitative studies. Disability and Rehabilitation. 2008;30:1329-1349.
34. Hinojosa MS, Rittman M, Hinojosa R, Rodriguez W. Racial/ethnic variation in recovery of motor function in stroke survivors: Role of informal caregivers. J Rehabil Res Dev. 2009;46:223-232.

35. McCurry SM, Logsdon RG, Teri L, Vitiello MV. Sleep disturbances in caregivers of persons with dementia: Contributing factors and treatment implications. Sleep Med Rev. 2007;11:143-153.

36. Yüksel G, Varlıbaş F, Karlıkaya G, Şıpka Y, Tireli H. Parkinson hastalığında bakıcı yükü. Parkinson Hastalıkları Hareket Bozukluğu Dergisi. 2007;10:26-34.

37. Carod-Artal FJ, Ferreira Coral L, Trizotto DS, Menezes Moreira C. Burden and perceived health status among caregivers of stroke patients. Cerebrovasc Dis. 2009;28:472-480.

38. Creese J, Bedard M, Brazil K, Chambers L. Sleep disturbances in spousal caregivers of individuals with Alzheimer's disease. Int Psychogeriatr. 2008;20:149-161.

39. Rausch SM, Baker K, Bounmee J. Sleep disturbances in caregivers of patients with end-stage congestive heart failure: Part I The problem. Prog Cardiovasc Nurs. 2007;22:38-40.

40. Das S, Hazra A, Ray BK, Ghosal M, Banerjee TK, Roy T, et al. Burden among stroke caregivers: Results of a community-based study from Kolkata, India. Stroke. 2010;41:2965-2968.

Copyright ( $\odot 2016$ The Author(s); This is an open-access article distributed under the terms of the Creative Commons Attribution License (http://creativecommons. org/licenses/by/4.0), which permits unrestricted use, distribution, and reproduction in any medium, provided the original work is properly cited. All Rights reserved by international journal of Medical Science and Discovery. 